\title{
Factors associated with the performance of episiotomy
}

\author{
Fatores associados à realização de episiotomia \\ Factores relacionados a la realización de episiotomía
}

Bruna Menezes Aguiar'
ORCID: 0000-0002-9394-4128

Thales Philipe Rodrigues da Silva' ORCID: 0000-0002-7115-0925

Samire Lopes Pereira' ORCID: 0000-0003-0668-1583

Ana Maria Magalhães Sousa" ORCID: 0000-0002-7096-592X

Roberta Barbosa Guerra "I' ORCID: 0000-0002-6683-6113

Kleyde Ventura de Souza' ORCID: 0000-0002-0971-1701

Fernanda Penido Matozinhos' ORCID: 0000-0003-1368-4248

'Universidade Federal de Minas Gerais. Belo Horizonte, Minas Gerais, Brazil.

"Instituto Villamil. Belo Horizonte, Minas Gerais, Brazil.

I" Hospital Maternidade Sofia Feldman. Belo Horizonte, Minas Gerais, Brazil.

How to cite this article: Aguiar BM, Silva TPR, Pereira SL, Sousa AMM, Guerra RB, Souza KV, et al. Factors associated with the performance of episiotomy. Rev Bras Enferm. 2020;73(Suppl 4):e20190899. doi: http://dx.doi.org/10.1590/0034-7167-2019-0899

\section{Corresponding author:}

Fernanda Penido Matozinhos E-mail: nandapenido@hotmail.com

EDITOR IN CHIEF: Antonio José de Almeida Filho ASSOCIATE EDITOR: Hugo Fernandes

\section{ABSTRACT}

Objective: To analyze the factors associated with the performance of episiotomy. Methods: Cross-sectional study, developed with data from the research"Born in Belo Horizonte: Labor and birth survey," "conducted with 577 women who had their children via vaginal birth. In order to verify the magnitude of the association between episiotomy and its possible determinants, logistic regression models were constructed to estimate the odds ratio. Results: Episiotomy was performed in $26.34 \%$ of women, and $59.21 \%$ knew they had been subjected to it. We observed that younger women, primiparous women, women assisted by a professional other than the obstetric nurse and women who had their babies in a private hospital have an increased chance of being submitted to this procedure. Conclusion: Considering the rates of episiotomy, this study highlights the need for the absolute contraindication to indiscriminate performing it.

Descriptors: Episiotomy; Socioeconomic Factors; Parity; Maternal age; Obstetric Nursing.

\section{RESUMO}

Objetivo: Avaliar os fatores associados à realização de episiotomia. Métodos: Estudo transversal, desenvolvido com dados da pesquisa"Nascer em Belo Horizonte: Inquérito sobre o parto e nascimento", realizada com 577 mulheres que tiveram seus filhos por via vaginal. Para verificar a magnitude da associação entre a realização de episiotomia e seus possíveis determinantes, foram construídos modelos de regressão logística para estimar a odds ratio. Resultados: A episiotomia foi realizada em $26,34 \%$ das mulheres; e, destas, 59,21\% sabiam que haviam sido submetidas a ela. Observou-se que mulheres mais jovens, primigestas, mulheres assistidas por profissional que não o enfermeiro obstetra e mulheres que tiveram seus bebês em hospital privado apresentam aumento na chance de serem submetidas a esse procedimento. Conclusão: Considerando as taxas do uso da episiotomia, este estudo destaca a necessidade de contraindicação absoluta de sua realização indiscriminada.

Descritores: Episiotomia; Fatores Socioeconômicos; Paridade; Idade Materna; Enfermagem Obstétrica.

\section{RESUMEN}

Objetivo: Evaluar los factores relacionados a la realización de episiotomía. Métodos: Estudio transversal, desarrollado con datos de la investigación "Nascer en Belo Horizonte: Averiguación sobre el parto y nacimiento", realizada con 577 mujeres que tuvieron sus hijos por vía vaginal. Para verificar la magnitud de la relación entre la realización de episiotomía y sus posibles determinantes, han sido construidos modelos de regresión logística para estimar la odds ratio. Resultados: La episiotomía ha sido realizada en $26,34 \%$ de las mujeres; $y$, de estas, 59,21\% sabían que habían sido sometidas a ella. Se observó que mujeres más jóvenes, primigestas, mujeres asistidas por profesional que no sea enfermero obstetra y mujeres que tuvieron sus bebés en hospital privado presentan aumento en la chance de ser sometidas a eso procedimiento. Conclusión: Considerando las tajas del uso de la episiotomía, este estudio destaca la necesidad de contraindicación absoluta de su realización indiscriminada. Descriptores: Episiotomía; Factores Socioeconómicos; Paridad; Edad Materna; Enfermería Obstétrica. 


\section{INTRODUCTION}

For a long time, the process of giving birth was considered natural and private for women, shared with other women, their relatives, and midwives, or comadres. Over the years, it has been replaced by a model of obstetric care based on labor and birth hospitalization, promoting a set of interventional obstetric practices $^{(1)}$.

These have made the global obstetric scenario, often violent. When performed without clinical indication, such practices may increase the risk of complications in the postpartum period. One of the obstetric practices considered interventional is episiotomy ${ }^{(1)}$.

It is one of the most common obstetric interventions in the world, and some countries considered it a routine procedure. It consists of the enlargement of the vaginal opening through a surgical incision in the perineum and can be performed by physicians and obstetric nurses ${ }^{(2)}$. Episiotomy rates increased substantially during the first half of the twentieth century, due to the medicalization process of childbirth and for justifying vaginal births occurring without complications ${ }^{(3)}$.

The World Health Organization (WHO) recommends that the rate of episiotomy in an institution does not exceed $10 \%{ }^{(4)}$. There is a variation in these indices according to the country studied: for example, in France, it was performed in $19.9 \%$ of births ${ }^{(5)}$. In Colombia and Spain, the rate was $30.48 \%$ and $50 \%$, respectively ${ }^{(6-7)}$. A 2018 systematic review, which assessed trends in the practice of episiotomy, observed a range of variation of $5 \%$ in Denmark to more than $90 \%$ in some Asian countries ${ }^{(8)}$. In Brazil, it was $16 \%$, varying according to parity: $27.40 \%$ in primiparous women and $3.40 \%$ in multiparous women ${ }^{(8)}$. According to a national study carried out with survey data from the Rede Cegonha evaluation, the proportion of episiotomy was $27.7 \%$ in public hospitals. However, data were self-reported by the parturient ${ }^{(9)}$. This procedure is performed in the Brazilian scenario in $27.7 \%$ of women in public institutions and $39.4 \%$ in the private sector ${ }^{(9)}$.

It is known that episiotomy can increase the extension of perineal lacerations and increase the risk of infection for women, hemorrhage, pelvic floor dysfunction, dyspareunia, rectovaginal fistulas, hematomas, among others. Such complications have negative impacts on the parturient's quality of life and the maternal-fetal relationship, in addition to being related to higher expenses in the health system, which increases the length of hospital stay ${ }^{(2,10)}$.

It is noteworthy that, currently, there is no evidence to support the need for episiotomy in routine care. However, some factors predispose women to a higher risk of being subjected to this procedure, such as: being primiparous, in addition to the prematurity, weight, and vitality of the newborn ${ }^{(11-12)}$. Using epidural analgesia, instrumental delivery, and synthetic oxytocin to induce labor and deliveries over 41 weeks also have a higher chance of episiotomy performance ${ }^{(7)}$.

This research advances, therefore, concerning existing studies in the Brazilian context on the subject.

\section{OBJECTIVE}

To analyze the factors associated with the performance of episiotomy.

\section{METHODS}

\section{Ethical aspects}

This study was approved by the Ethics and Research Committee of Universidade Federal de Minas Gerais and by the Ethics Committees of the maternities involved. Data collection started after obtaining the parturients' signature of the Free and Informed Consent Form.

\section{Design, period and place of study}

This research is an observational study with a cross-sectional design, developed with data from the research"Born in Belo Horizonte: Labor and birth survey," carried out in seven maternity hospitals that serve the public health network and in four maternities that attend the Private Health Insurance and Plans network in Belo Horizonte, Minas Gerais. This research used the same method of sampling, logistics, and material resources as the nationwide study entitled "Born in Brazil: Labor and birth survey"(13).

\section{Sample}

The sample consisted of puerperal women who had children born alive in 2011 in hospitals with 500 or more live births in 2007, according to the Sistema de Informações sobre Nascidos Vivos (SINASC - Brazil Live Birth Information System). The cesarean rate for 2007 was used o calculate the sample size. The sampling process took place in three stages. The first included selecting the hospitals, and only those with 500 or more live births in 2007 were included in this process. The second stage used the inverse sampling method, which defines the number of interviews carried out as a stopping rule for the consecutive sample of research days. To consider the difference between the number of live births on weekdays and weekends, a minimum of seven consecutive days per hospital was mandatory. The last stage of sampling was selecting the mothers who were eligible to participate in the study, which was done randomly. Postpartum women with severe mental disorders, homeless (or living on the street), foreigners who did not understand Portuguese, deaf, and convicted by court order were considered ineligible ${ }^{(13)}$.

This study included women admitted to the maternity hospitals selected at the time of delivery, who had their children via vaginal birth, and agreed to participate in the research $(n=600)$.

Data collection took place from November 2011 to March 2013 through interviews with mothers at least six hours after delivery - this time being pre-established as the minimum interval for postpartum rest ${ }^{(13)}$ - and by investigating their medical records. The interviews were conducted by trained nurses, the data, recorded on netbooks, and then exported to a particular server.

The final sample consisted of 577 parturients, as 23 women were excluded due to the lack of information in the medical record regarding whether episiotomy was performed.

\section{Study Protocol}

As the outcome variable of this study, we considered episiotomy, where: 0 - not performed; and 1 - performed. 
The variables included in this study refer to sociodemographic characteristics, prior obstetric, clinical, pregnancy, childbirth procedures, in addition to the hospital's funding source (public or private).

We also created a variable called"complications (clinical or obstetric) during pregnancy or childbirth," which could influence the higher chance of an episiotomy. It was considered "complications" if there were at least one of the following conditions present: fetal distress, the threat of premature birth, or prelabor rupture of membranes ${ }^{(11)}$.

\section{Analysis of results and statistics}

For data analysis, the Stata statistical package, version 14.0, was used.

The estimates were shown in proportions (\%) and their respective confidence intervals $(95 \% \mathrm{Cl})$. Data were presented using median and interquartile range (IQR) for quantitative variables after asymmetry was verified by the Shapiro-Wilk test. In order to verify the magnitude of the association between episiotomy and its possible determinants (variables-exposition), logistic regression models were constructed to estimate the odds ratio (OR).

For the multivariate regression model, the backward method was adopted, and we included all variables of interest related to a level of statistical significance below $20 \%$ in the bivariate analysis, removing one by one. However, theoretical criteria were also used in the statistical modeling process ${ }^{(11)}$. The Hosmer-Lemeshow's goodness test was used to evaluate the adjustments of the final model.

\section{RESULTS}

The sample consisted of 577 women, with a median age of 26 years old (IQR $=21-31)$, self-reported parda (brown color) $(69.67 \%)$, women who had paid work (53.38\%), who had secondary education (56.60\%) and were in a domestic relationship (66.72\%) (Table 1 ). We highlight that the totals of the variables may vary due to the different rates of non-response.

Table 1 - Sample profile, Belo Horizonte, Minas Gerais, Brazil, 2011-2013

\begin{tabular}{lcc} 
& $\mathbf{n}(\%)$ & $\mathbf{9 5 \%} \mathbf{C l}$ \\
\hline Age * & $26(21-31)$ & \\
Color & & \\
$\quad$ White & $123(21.32)$ & $18.15-24.56$ \\
$\quad$ Black & $52(9.01)$ & $6.92-11.64$ \\
$\quad$ Parda** & $402(69.67)$ & $65.78-73.29$ \\
Paid work & & \\
$\quad$ No & $269(46.62)$ & $42.56-50.71$ \\
$\quad$ Yes & $308(53.38)$ & $49.28-57.43$ \\
Education & $200(34.72)$ & $30.93-38.71$ \\
$\quad$ Primary school & $326(56.60)$ & $52.50-60.60$ \\
$\quad$ Secondary education & $50(8.68)$ & $6.63-11.28$ \\
$\quad$ Higher education & & \\
Marital Status & $385(66.72)$ & $62.76-70.46$ \\
$\quad$ Domestic Relationship & $192(33.28)$ & $29.53-37.23$ \\
$\quad$ No partner & & \\
\hline Note: ${ }^{*}$ Median (IQR); ** Include: Parda, brown, Asian descendants and indigenous. $95 \% \mathrm{Cl}$ \\
Confidence Interval
\end{tabular}

Episiotomy was performed in 152 (26.34\%) of the women in the sample in this study. Of these, 90 (59.21\%) knew that they had undergone this procedure (data not shown).

Table 2 shows the possible factors associated with the procedure. Regarding socioeconomic variables, were associated with episiotomy: age and education. In the obstetric profile, episiotomy was associated with: primipregnancy, complications in labor, delivery position "lying on the back with legs raised," professional who assisted the delivery and funding of the hospital of delivery (Table 2).

Table 2 - Socioeconomic and obstetric factors associated with episiotomy, Belo Horizonte, Minas Gerais, Brazil, 2011-2013

\begin{tabular}{|c|c|c|c|}
\hline $\begin{array}{l}\text { Variables } \\
\text { Socioeconomic }\end{array}$ & $\begin{array}{c}\text { Episiotomy } \\
\text { No } \\
\mathbf{n}(\%)\end{array}$ & $\begin{array}{l}\text { Yes } \\
\text { n(\%) }\end{array}$ & $\begin{array}{l}\text { Raw model* } \\
\text { OR }(95 \% \mathrm{Cl})\end{array}$ \\
\hline $\operatorname{Age}^{*}$ & $26(22-31)$ & $24(20-28.5)$ & $0.94(0.92-0.97)$ \\
\hline \multicolumn{4}{|l|}{ Color } \\
\hline White & $84(68.29)$ & 39(31.71) & 1 \\
\hline Black & $41(78.85)$ & $11(21.15)$ & $0.57(0.26-1.24)$ \\
\hline Parda* & $300(74.63)$ & $102(25.37)$ & $0.73(0.47-1.13)$ \\
\hline \multicolumn{4}{|l|}{ Paid work } \\
\hline Yes & 199(73.98) & $70(26.02)$ & 1 \\
\hline No & $226(73.38)$ & $82(26.62)$ & $1.03(0.71-1.49)$ \\
\hline \multicolumn{4}{|l|}{ Education } \\
\hline Primary school & $162(81.00)$ & $38(19.00)$ & 1 \\
\hline Secondary education & $229(70.25)$ & $97(28.75)$ & $1.80(1.17-2.76)$ \\
\hline Higher education & $33(66.00)$ & $17(34.00)$ & $2.19(1.10-4.35)$ \\
\hline \multicolumn{4}{|l|}{ Marital Status } \\
\hline Domestic Relationship & $287(74.55)$ & $98(25.45)$ & 1 \\
\hline No partner & $138(71.88)$ & $54(28.13)$ & $1.14(0.77-1.69)$ \\
\hline \multicolumn{4}{|l|}{ Obstetric } \\
\hline \multicolumn{4}{|l|}{ Primiparous } \\
\hline No & $269(82.77)$ & $46(17.23)$ & 1 \\
\hline Yes & $156(61.90)$ & $96(38.10)$ & $2.95(2.01-4.34)$ \\
\hline \multicolumn{4}{|l|}{ Use of oxytocin during labor } \\
\hline No & $221(76.47)$ & $68(23.53)$ & 1 \\
\hline Yes & $199(70.32)$ & $84(29.68)$ & $1.37(0.94-1.99)$ \\
\hline \multicolumn{4}{|l|}{ Complications in labor } \\
\hline No & $383(74.22)$ & 133(25.78) & 1 \\
\hline Yes & $42(68.85)$ & $19(31.15)$ & $1.30(0.73-2.31)$ \\
\hline \multicolumn{4}{|l|}{$\begin{array}{l}\text { Position "lying on the back } \\
\text { with legs raised" }\end{array}$} \\
\hline No & $339(71.22)$ & 137(28.78) & 1 \\
\hline Yes & 78(91.76) & $7(8.24)$ & $0.22(0.09-0.49)$ \\
\hline \multicolumn{4}{|l|}{ Baby } \\
\hline Full term & $363(73.48)$ & $131(26.52)$ & 1 \\
\hline Premature & $37(75.51)$ & $12(24.49)$ & $0.89(0.45-1.77)$ \\
\hline \multicolumn{4}{|l|}{ Birth weight (g) } \\
\hline Up to 2,499 & $34(79.07)$ & 9(20.93) & 1 \\
\hline 2,500 to 3,999 & $377(73.20)$ & $138(26.80)$ & $1.38(0.64-2.95)$ \\
\hline 4,000 or more & $9(69.23)$ & 4(30.77) & $1.67(0.41-6.72)$ \\
\hline \multicolumn{4}{|l|}{$\begin{array}{l}\text { Professional who attended the } \\
\text { birth }\end{array}$} \\
\hline Obstetric nurse & 164(95.91) & 7(4.09) & 1 \\
\hline Physician & $259(64.43)$ & $143(35.57)$ & $3.59(2.43-5.32)$ \\
\hline \multicolumn{4}{|l|}{$\begin{array}{l}\text { Funding of the hospital of } \\
\text { delivery }\end{array}$} \\
\hline Public & $390(76.92)$ & $117(23.08)$ & 1 \\
\hline Private & $35(50.00)$ & $35(50.00)$ & $3.33(1.99-5.56)$ \\
\hline
\end{tabular}

Table 3 shows the final adjusted model and the factors associated with episiotomy performance. Regarding the socioeconomic profile, we observed that an increase in the woman's age of one year reduced, on average, $0.94(95 \% \mathrm{Cl} 0.90-0.99)$ times the chance of being submitted to this procedure (Table 3 ).

Regarding the obstetric profile, on average, primiparous women increased by 2.15 (95\% Cl 1.32-3.49) times the chance of being submitted to episiotomy compared to multiparous women. Women assisted by a professional other than the obstetric nurse showed, on average, an increase of $3.29(95 \% \mathrm{Cl} 2.19-4.94)$ times in the 
chance of undergoing the procedure when compared with the pregnant women who had the obstetric nurse professional at the time of childbirth. Finally, pregnant women who had their babies in a private hospital showed an average increase of $2.50(95 \% \mathrm{Cl}$ 1.34-4.64) times in the chance of undergoing episiotomy compared to those who had their babies in a public hospital ( Table 3).

Table 3 - The adjusted final model of factors associated with episiotomy Belo Horizonte, Minas Gerais, Brazil, 2011-2013

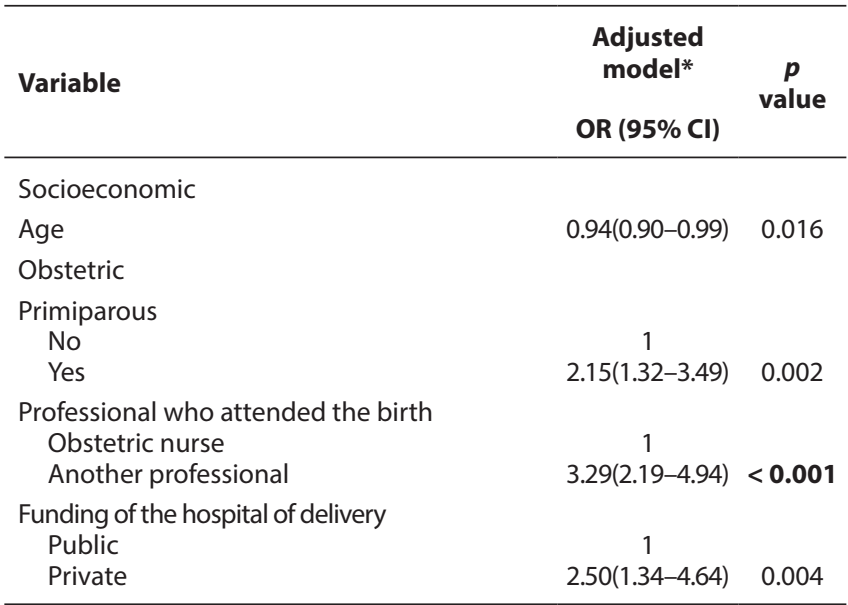

Note: OR - odds ratio; 95\% Cl- confidence intervals; * $p$ (Hosmer-Lemeshow test) $=0.4158$ model adjusted for education, premature babies, complications during labor and birth weight.

\section{DISCUSSION}

The results showed that episiotomy was performed in $26.34 \%$ of parturients, and $59.21 \%$ knew that they had undergone this procedure. As for the factors associated with this procedure's performance, we found that younger women, primiparous women, women assisted by a professional other than the obstetric nurse and women who had their babies in a private hospital have an increased chance of being subjected to it.

Regarding the performance of the episiotomy, the WHO issued recommendations on standards of treatment and care related to parturient women. These were subsequently ratified by the Ministry of Health and were called good practices in the care of normal birth. They aim to guide the professional's conduct. They are classified as: clearly useful practices that should be encouraged, clearly harmful or ineffective practices that must be eliminated, and practices used inappropriately at the time of labor and delivery; this category includes the episiotomy ${ }^{(1,14-15)}$.

In this study, among women who underwent episiotomy, $40.79 \%$ did not know that they had been submitted to it. A recent study showed that most women undergo a cesarean section, episiotomy, labor induction, and vaginal exams without their consent ${ }^{(16)}$. These results indicate that unnecessary interventions during labor violate women's rights and their autonomy in the process of giving birth. Often, certain behaviors are caused by impatience for waiting for the birth to occur physiologically, disrespecting the autonomy of women in the parturition process ${ }^{(16)}$. Also, episiotomy violates women's sexual and reproductive rights, due to the fact of subjecting a healthy body to harm, without having a benefit established by scientific evidence ${ }^{(17)}$.
Episiotomy may increase bleeding, infection, wound dehiscence, hematoma formation, perineal pain, and extended rupture in the anal and rectal sphincter. There are also possible long-term complications, such as dyspareunia, anorectal dysfunction, and sexual dysfunction ${ }^{(2,10)}$. It is noteworthy that the use of good practices during labor, recommended by $\mathrm{WHO}$, can reduce the likelihood of unnecessary interventions and have positive effects on the delivery experience of these women ${ }^{(14,16)}$.

The results of this study showed that younger women and primiparous women were more likely to being submitted to an episiotomy. A systematic review of 2019 confirms these findings ${ }^{(18)}$. This procedure's performance in primiparous women is associated with higher chances of obstetric lesions of the anal sphincter ${ }^{(19)}$. Authors demonstrate that the main arguments of professionals who make the inappropriate use of episiotomy are related to perineal stiffness, (justifying that it could lead to prolonging the period of the detachment of the cephalic pole), as well as to the woman's inexperience with the labor ${ }^{(2)}$. We reinforce that such arguments are not based on scientific evidence, since the model of childbirth assistance, with excessive use of interventions, is not supported by international guidelines or studies ${ }^{(3,20)}$. Adopting clearly useful practices that should be encouraged, such as the parturient woman's free movement, using the partogram, and performing non-pharmacological methods for pain relief, can solve these justifications ${ }^{(16)}$.

In this study, parturients assisted by obstetric nurses were less likely to undergo episiotomy. Other studies confirm this finding, in addition to highlighting higher rates of intact perineum and, consequently, less occurrence of sphincter rupture ${ }^{(21)}$. Furthermore, in this sense, a meta-analysis ${ }^{(22)}$ carried out with 17,674 participants showed that women assisted by a model "Midwife-led continuity" have a reduction in the risk ratio of undergoing this procedure, with an average of 0.84 (CI95\% 0.77-0.92) (22). Another study, carried out with 480 records of vaginal deliveries in Rio de Janeiro, showed that parturients accompanied by nurses had a lower rate of receiving episiotomy ${ }^{(23)}$.

Obstetric nurses use several techniques that contribute to the parturient's relaxation and perineal protection, such as breathing exercises, pelvic movements, and a warm bath ${ }^{(24)}$. Restricting the number of care providers, reducing the number of vaginal exams and woman's free choice of position during labor and delivery, determines the quality of childbirth care, which nurses encourage ${ }^{(21,25)}$.

Finally, the study found that the chance of episiotomy occurring was higher in private institutions. This result corroborates data from the 2019 systematic review, which shows that hospital financing may be a risk factor for the performance of this surgical incision $^{(18)}$. In general, women treated in public hospitals have more access to good practices in childbirth and birth care, such as non-pharmacological methods of pain relief, free choice of positions during childbirth, and a greater probability of moving, reducing the chance of undergoing episiotomy. This fact may be related to the actions and incentives created by the Ministry of Health to promote humanized and vaginal delivery, through the disseminating manuals and ordinances, adapting the environment and qualifying the professionals involved with delivery and birth ${ }^{(15)}$. 
A study carried out in a public maternity hospital in and Londrina, Paraná, demonstrated a 7.3\% proportion of episiotomy ${ }^{(26)}$, lower than that recommended by $\mathrm{WHO}^{(4)}$. Another study revealed higher rates of obstetric intervention among women who delivered in private hospitals (47\%) when compared to the rates of public hospitals $(29 \%)^{(27)}$. It is noteworthy that the Agência Nacional de Saúde Suplementar (ANS - National Regulatory Agency for Private Health Insurance and Plans) established some measures to encourage normal childbirth, such as the mandatory use of the partograph and the pregnant woman's card ${ }^{(28)}$.

Episiotomy also impacts hospital care costs, as demonstrated by a study that evaluated two public maternity hospitals in Rio de Janeiro and one philanthropic hospital in Belo Horizonte ${ }^{(29)}$. Results found that the last institution had lower episiotomy indexes (3.1\%), reflecting on lower costs of inputs used, due to the reduced frequency of invasive practices, and may also relate to the care provided $-80 \%$ of vaginal deliveries were assisted by obstetric nurses ${ }^{(29)}$.

\section{Study Limitations}

Finally, it is relevant to recognize some limitations in this research. First, this is a cross-sectional study, which makes it impossible to identify the temporality of the associations. It is also noteworthy the loss of some data, intrinsic to the fact that data collection was also performed in medical records. However, we carried out a sensitivity analysis comparing the final sample (of 577 parturients) and the 23 excluded women - due to lack of information in the medical records. Results demonstrated that the losses occurred randomly, not affecting the estimates of this study.

\section{Contributions to the nursing field}

There are many advances of this work in the area of health and nursing, because the results provide valuable epidemiological information, emphasizing that, in public institutions and with obstetric nursing, active in the care of labor and delivery, there are better perspectives compared to private institutions and with emphasis on more interventional care. Thus, guaranteeing humanized care can undoubtedly contribute to the reduction of episiotomy rates.

\section{CONCLUSION}

Episiotomy was performed in $26.34 \%$ of women; and, of these, $59.21 \%$ knew they had been subjected to it. We observed that younger women, primiparous women, women assisted by a professional other than the obstetric nurse and women who had their babies in a private hospital have an increased chance of being submitted to this procedure.

The results of this study raise reflection on the importance of fostering care actions and health care planning oriented at women with a profile pointed out in the results of this study, stimulating more humanized and holistic care models that consider the uniqueness of each woman and respect her autonomy. Furthermore, regarding the rates of use of episiotomy, this study highlights the need for absolute contraindication for indiscriminate performing it.

\section{REFERENCES}

1. Sousa AMM, Souza KV, Rezende EM, Martins EF, Campos D, Lansky S. Practices in childbirth care in maternity with inclusion of obstetric nurses in Belo Horizonte, Minas Gerais. Esc Anna Nery. 2016;20(2):324-31. doi: 10.5935/1414-8145.20160044

2. Nunes RD, Mapelli AV, Nazário NO, Traebert E, Seemann M, Traebert J. Avaliação dos fatores determinantes à realização da episiotomia no parto vaginal. Enferm Foco. 2019;10(1):71-5. doi: 10.21675/2357-707X.2019.v10.n1.1399

3. Jiang H, Qian X, Carroli G, Garner P. Selective versus routine use of episiotomy for vaginal birth. Cochrane Libr. 2017;(2). doi: 10.1002/14651858.CD000081.pub3

4. World Health Organization. WHO recommendations: intrapartum care for a positive childbirth experience [Internet]. Geneva; 2018[cited 2020 Apr 28]. Available from: https://apps.who.int/iris/bitstream/handle/10665/260178/9789241550215-eng.pdf;jsessionid=7249D951142 ADCD80C5CC49A30B618B0? sequence=1.

5. Goueslard K, Cottenet J, Roussot A, Clesse C, Sagot P, Quantin C. How did episiotomy rates change from 2007 to 2014 ? population-based study in France. BMC Pregnancy Childbirth. 2018;18(1):208-12. doi: 10.1186/s12884-018-1747-8

6. Mellizo-Gaviria AM, López-Veloza LM, Montoya-Mora R, Ortiz-Martínez RA, Gil-Walteros CC. Frequency of episiotomy and complications in the obstetrics service of Hospital Universitario San José, Popayán (Colombia), 2016. Exploration of maternal and perinatal factors associated with its performance. Rev Colomb Obstetr Ginecol. 2018;69(2):88-97. doi: 10.18597/rcog.3030

7. Ballesteros-Meseguer C, Carrillo-Garcia C, Meseguer-de-Pedro M, Jordana MC, Martinez-Roche ME. Episiotomy and its relationship to various clinical variables that influence its performance. Rev Latino-Am Enferm. 2016;24:e2793. doi: 0.1590/1518-8345.0334.2686

8. Clesse C, Lighezzolo-Alnot J, De Lavergne S, Hamlin S, Scheffler M. Statistical trends of episiotomy around the world: Comparative systematic review of changing practices. Health Care Women Int. 2018;39(6):644-62. doi: 10.1080/07399332.2018.1445253

9. Leal MC, Bittencourt SA, Pereira APE, Ayres BVS, Silva LBRA, Thomaz EBAF, et al. Avanços na assistência ao parto no Brasil: resultados preliminares de dois estudos avaliativos. Cad Saúde Pública. 2019;35(7):1-14. doi: 10.1590/0102-311X00223018

10. Azevedo M, Guilhem DB, Hobo TMW, Goulart MV. Avaliação da predominância da incontinência anal nos partos vaginal e cesáreo. Univ, Ciênc Saúde. 2017;15(2):101-6. doi: 10.5102/ucs.v15i2.4240

11. Aguiar M, Farley A, Hope L, Amin A, Shah P, Maneseki-Holland, S. Birth-Related perineal trauma in low-and middle-income countries: a systematic review and meta-analysis. Matern Child Health J. 2019;23:1048-70. doi: 10.1007/s10995-019-02732-5 
12. Leal MC, Pereira APE, Domingues RMSM, Filha MMT, Dias MAB, et al. Obstetric interventions during labor and childbirth in Brazilian low-risk women. Cad Saúde Pública. 2014;30(Suppl-1): S17-S32 . doi: 10.1590/0102-311X00151513

13. Vasconcellos MTL, Silva PLN, Pereira APE, Schilithz AOC, Souza-Jr PRB, Szwarcwald CL. Desenho da amostra Nascer no Brasil: Pesquisa Nacional sobre Parto e Nascimento. Cad Saúde Pública. 2014; 30 Supl: S49-58. doi: 10.1590/0102-311X00176013.

14. Silva TPR, Pena-Dumont E, Sousa AMM, Amorim T, Tavares LC, Nascimento DCP, et al. Obstetric Nursing in best practices of labor and delivery care. Rev Bras Enferm. 2019;72(Suppl 3): 235-42. doi: 10.1590/0034-7167-2018-0561

15. Ministério da Saúde (BR). Diretrizes nacionais de assistência ao parto normal [Internet]. Brasília: Ministério da Saúde; 2017 [cited 2020 Apr 28]. Available from: http://bvsms.saude.gov.br/bvs/publicacoes/diretrizes_nacionais_assistencia_parto_normal.pdf

16. Bohren MA, Mehrtash H, Fawole B, Maung TM, Balde MD, Maya E, et al. How women are treated during facility-based childbirth in four countries: a cross-sectional study with labour observations and community-based surveys. Lancet. 2019:1-14. doi: 10.1016/ S0140-6736(19)31992-0

17. Amorim MM, Coutinho IC, Melo I, Katz L. Selective episiotomy vs. implementation of a non-episiotomy protocol: a randomized clinical trial. Reprod Health. 2017;14(55):1-10. doi: 10.1186/s12978-017-0315-4

18. Clesse C, Lighezzolo-Alnot J, De Lavergne S, Hamlin S, Scheffler M. Factors related to episiotomy practice: an evidence-based medicine systematic review. J Obstetr Gynaecol. 2019;39(6):737-47. doi: 10.1080/01443615.2019.1581741

19. Mahgoub S, Piant H, Gaudineau A, Lefebvre F, Langer B, Koch A. Risk factors for obstetric anal sphincter injuries (OASIS) and the role of episiotomy: a retrospective series of 496 cases. Journal of gynecology obstetrics and human reproduction. 2019;48(8):657-662. doi: 10.1016/j.jogoh.2019.07.004

20. Sobieray NLEC, Souza BM. Prevalência de episiotomia e complicações perineais quando da sua realização ou não em uma maternidade de baixo risco do complexo HC/UFPR. Arq Med Hosp Fac Cien Med Santa Casa São Paulo. 2019;64(2):93-99. doi: https://doi. org/10.26432/1809-3019.2019.64.2.093

21. Dencker A, Smith V, McCann C, Begley C. Midwife-led maternity care in Ireland: a retrospective cohort study. BMC Pregnancy Childbirth. 2017;17(101):01-08. doi:10.1186/s12884-017-1285-9

22. Sandall J, Soltani H, Gates S, Shennan A, Devane D. Midwife-led continuity models versus other models of care for childbearing women. Cochrane Database Syst Rev. 2016;28(4):CD004667. doi: 10.1002/14651858.CD004667.pub5

23. Pereira, ALF, Araújo CS, Gouveia MSF, Potter VMP, Santana ALS, et al. Resultados maternos e neonatais dos partos normais de baixo risco assistidos por enfermeiras e médicos. Rev Eletr Enferm. 2012;14(4):831-40. doi: 10.5216/ree.v14i4.13665

24. Silva TF, Costa GAB, Pereira ALF. Cuidados de Enfermagem Obstétrica no Parto Normal. Esc Enferm UERJ. 2011;16(1):82-7. doi: 10.5380/ ce.v16i1.21116

25. Bodner-Adler B, Kimberger O, Griebaum J, Husslein P, Bodner K. A ten-year study of midwife-led care at an Austrian tertiary care center: a retrospective analysis with special consideration of perineal trauma. BMC Pregnancy Childbirth. 2017;17(1):357. doi: 10.1186/ s12884-017-1544-9

26. Wielgalnezuk RP, Pinto KRTF, Zani AV, Berbardy CCF, Parada CMGL, Lopes DBM, et al. Perfil de puérperas e de seus neonatos em maternidades públicas. REAS. 2019;11(7):1-9. doi: 10.25248/reas.e605.2019

27. Dahlen HG, Tracy S, Tracy M, Bisits A, Brown C, Thornton C. Rates of obstetric intervention among low-risk women giving birth in private and public hospitals in NSW: a population-based descriptive study. BMJ Open. 2012;2(5):1-8. doi: 10.1136/bmjopen-2012-001723

28. Agência Nacional de Saúde Suplementar. Resolução Normativa-RN № 368, de 6 de janeiro de 2015. Dispõe sobre o direito de acesso à informação das beneficiárias aos percentuais de cirurgias cesáreas e de partos normais, por operadora, por estabelecimento de saúde e por médico e sobre a utilização do partograma do cartão da gestante e da carta de informação à gestante no âmbito da saúde suplementar [Internet]. Brasília, DF: ANS; 2015[cited 2020 Apr 28]. Available from: http://www.ans.gov.br/component/legislacao/?view=legislacao\&task= TextoLei\&f ormat=raw\&id=Mjg5Mg==

29. Entringer AP, Pinto MFT, Gomes MASM. Análise de custos da atenção hospitalar ao parto vaginal e à cesariana eletiva para gestantes de risco habitual no Sistema Único de Saúde. Ciên Saúde Colet. 2019;24(4):1527-36. doi: 10.1590/1413-81232018244.06962017z 